\title{
Repeatability precision measurement evaluation of the system for self-monitoring of blood glucose GL 44 following DIN EN ISO 15197:2015
}

\author{
Eckhard Salzsieder ${ }^{1 *}$, Puchert $A^{1}$, Ernst-Joachim Freyse ${ }^{1}$ and Berg $\mathrm{S}^{1,2}$ \\ ${ }^{1}$ Institute of Diabetes, Gerhardt Katsch, Karlsburg, Germany \\ ${ }^{2}$ University Medicine Greifswald, Germany
}

\begin{abstract}
Abbreviations: CE: Conformite Europeene; ISO: International Organization for Standardization; SMBG: Self-Monitoring of Blood Glucose.
\end{abstract}

\section{Introduction}

Ongoing standardized verification of the repeatability precision measurement of blood glucose meter systems for self-monitoring post-launch is important clinically and helps confirm appropriate continues performance of self-monitoring blood glucose (SMBG) - systems [1]. In addition, publication of such studies is increasingly becoming a component of evidence-based purchase decision making. ISO 15197:2015, [2] for which mandatory compliance is recommended for SMBG systems by 2015, [3] has tighter accuracy requirements than ISO 15197:2003, [4-6]

In the present study, a postmarketing evaluation of the CE-marked GL44 system for repeatability precision were performed in accordance with ISO 15197:2015 protocols and requirements. The GL44 system were supplied in Germany from the Beurer GmbH, Germany.

Venous blood from a test person was sampled in LithiumHeparine tubes (Vacutainer, Saarstedt, Germany). After well mixing, the blood was aliquoted into five samples of $300 \mu$ each with glucose concentrations in 5 different ranges as revealed by measurements with the YSI 2300 STAT PLUS reference device: Hematocrit values of all samples used were between $43 \%$ and $44 \%$ and therefore in the required range, given in the user manual, between $35 \%$ and $50 \%$ (Table 1).

Test devices: In the study, ten glucose monitors with different serial numbers were used. Serial number and study code of the glucose monitors (Beurer GL44) (Table 2):

Test strip lots: In total, 600 test strips from each of the 3 lots were available. The following lots were included into the tests (Table 3):

The control measurements, done before the blood tests, were performed using three glucose control solutions with the following characteristics (Table 4):

Table 1. Self-monitoring blood glucose

\begin{tabular}{|l|c|}
\hline Range & Actually measured blood glucose values \\
\hline $1: 30-50 \mathrm{mg} / \mathrm{dl}$ & $41 \mathrm{mg} / \mathrm{dl}$ \\
\hline $2: 51-110 \mathrm{mg} / \mathrm{dl}$ & $91 \mathrm{mg} / \mathrm{dl}$ \\
\hline $3: \quad 111-150 \mathrm{mg} / \mathrm{dl}$ & $123 \mathrm{mg} / \mathrm{dl}$ \\
\hline $4: \quad 151-250 \mathrm{mg} / \mathrm{dl}$ & $169 \mathrm{mg} / \mathrm{dl}$ \\
\hline $5: 251-400 \mathrm{mg} / \mathrm{dl}$ & $281 \mathrm{mg} / \mathrm{dl}$ \\
\hline
\end{tabular}

Table 2. Serial number and study code of the glucose monitors

\begin{tabular}{|c|c|}
\hline Study code & Serial number \\
\hline GC 1 & GL44T1 \\
\hline GC 2 & GL44T2 \\
\hline GC 3 & GL44T3 \\
\hline GC 4 & GL44T4 \\
\hline GC 5 & GL44T5 \\
\hline GC 6 & GL44T6 \\
\hline GC 7 & GL44T7 \\
\hline GC 8 & GL44T8 \\
\hline GC 9 & GL44T9 \\
\hline GC 10 & GL44T10 \\
\hline GC 11 & GL44T11 (not used) \\
\hline
\end{tabular}

Table 3. Lot numbering and expiration date

\begin{tabular}{|c|c|c|}
\hline & Test strips \\
\hline Numbering & Lot No. & Expiration date \\
\hline Lot 1 & $\mathrm{~A} 10 / 1$ & $2017 / 03$ \\
\hline Lot 2 & $\mathrm{~A} 10 / 3$ & $2017 / 03$ \\
\hline Lot 3 & $\mathrm{~A} 10 / 5$ & $2017 / 03$ \\
\hline
\end{tabular}

Table 4. Control measurements, done before the blood tests

\begin{tabular}{|c|c|c|c|}
\hline Control solution & Lot Number & Expiration date & Target range (mg/dl) \\
\hline Level high & A04/3 & $2016 / 07$ & $308-386$ \\
\hline Level normal & A04/3 & $2016 / 12$ & $124-154$ \\
\hline Level low & A04/3 & $2016 / 08$ & $65-81$ \\
\hline
\end{tabular}

For setting glucose concentrations between $30-50 \mathrm{mg} / \mathrm{dl}$, the blood was stored at $37^{\circ} \mathrm{C}$.

To set the higher concentrations of glucose $(>120 \mathrm{mg} / \mathrm{dl})$ the Lithium-heparin blood samples ( $300 \mu \mathrm{l}$ each) were spiked with a glucose solution (Glucose $40 \%$, B. Braun, Melsungen, Germany). Before the measurements were started in the above-mentioned ranges, a $100 \mu \mathrm{l}$ aliquot was separated from each $300 \mu$ blood sample. These $100 \mu \mathrm{l}$ samples were taken to separate plasma for the reference measurements" before". After the test measurements, the plasma was separated from

${ }^{\star}$ Correspondence to: Eckhard Salzsieder, Institute of Diabetes, Gerhardt Katsch, Karlsburg, Germany, E-mail: salzsied@diabetes-karlsburg.de

Received: October 04, 2019; Accepted: October 21, 2019; Published: October 23,2019 
the remaining blood sample volume and it was used for the reference measurements "after" the tests.

After reference sample separation, drops of blood were placed on the designated area of the test strip by means of a pipette ( 10 glucose monitors were handled in parallel). For each of the three included test lots, ten measurements on the ten monitors each were performed.

\section{Results}

The statistical analysis for each test lot and each glucose meter within the five glucose concentration ranges are given in Table 5.

Analysis of mean, standard deviation (SD) und coefficient of variation $(\mathrm{CV})$ for each test lot and each glucose meter in the 5 glucose concentration ranges of $41 \mathrm{mg} / \mathrm{dl}, 91 \mathrm{mg} / \mathrm{dl}, 123 \mathrm{mg} / \mathrm{dl}, 169 \mathrm{mg} / \mathrm{dl}$ and $281 \mathrm{mg} / \mathrm{dl}$, respectively.

Analysis of pooled mean values, pooled standard deviation (SD) and pooled coefficient of variation (CV)in summary of the 3 test lots (Table 6) in the 5 glucose concentration ranges of $41 \mathrm{mg} / \mathrm{dl}, 91 \mathrm{mg} / \mathrm{dl}$, $123 \mathrm{mg} / \mathrm{dl}, 169 \mathrm{mg} / \mathrm{dl}$ and $281 \mathrm{mg} / \mathrm{dl}$.

The pooled coefficient of variation was less than $5 \%$ for all test Lots and in all glucose concentration ranges of $>100 \mathrm{mg} / \mathrm{dl}$. Highest single coefficient of variation in the concentration ranges $>100 \mathrm{mg} / \mathrm{dl}$ for a glucose meter was found to be $6.4 \%$. At glucose concentrations of $<100 \mathrm{mg} / \mathrm{dl}$ the pooled standard deviation did not exceeded the $95 \%$ confidence interval.

Table 5. Statistical analysis for each test lot and each glucose meter within the five glucose concentration ranges

\begin{tabular}{|c|c|c|c|c|c|c|c|c|c|c|c|}
\hline \multicolumn{4}{|c|}{ Lot 1} & \multicolumn{4}{|c|}{ Lot 2} & \multicolumn{4}{|c|}{ Lot 3} \\
\hline \multicolumn{12}{|c|}{$41 \mathrm{mg} / \mathrm{dl}$} \\
\hline meter & mean & $\mathrm{SD}$ & $\mathrm{CV}$ & meter & mean & $\mathrm{SD}$ & $\mathrm{CV}$ & meter & mean & SD & $\mathrm{CV}$ \\
\hline 1 & 35 & 1.7 & 4.9 & 1 & 33 & 1.2 & 3.6 & 1 & 30 & 1.6 & 5.3 \\
\hline 2 & 37 & 1.1 & 3.0 & 2 & 34 & 1.9 & 5.6 & 2 & 31 & 2.1 & 6.8 \\
\hline 3 & 39 & 1.0 & 2.6 & 3 & 34 & 1.7 & 5.0 & 3 & 33 & 1.9 & 5.8 \\
\hline 4 & 37 & 1.5 & 4.1 & 4 & 34 & 1.5 & 4.4 & 4 & 32 & 1.3 & 4.1 \\
\hline 5 & 38 & 1.2 & 3.2 & 5 & 34 & 1.8 & 5.3 & 5 & 32 & 1.6 & 5.0 \\
\hline 6 & 38 & 0.9 & 2.4 & 6 & 34 & 1.8 & 5.3 & 6 & 31 & 1.2 & 3.9 \\
\hline 7 & 38 & 1.9 & 5.0 & 7 & 36 & 1.4 & 3.9 & 7 & 31 & 1.7 & 5.5 \\
\hline 8 & 36 & 1.2 & 3.3 & 8 & 35 & 1.4 & 4.0 & 8 & 33 & 1.2 & 3.6 \\
\hline 9 & 34 & 1.8 & 5.3 & 9 & 33 & 1.4 & 4.2 & 9 & 31 & 2.7 & 8.7 \\
\hline 10 & 33 & 1.4 & 4.2 & 10 & 32 & 1.2 & 3.8 & 10 & 30 & 0.9 & 3.0 \\
\hline mean & 37 & 1.4 & 3.8 & mean & 34 & 1.5 & 4.5 & mean & 32 & 1.6 & 5.1 \\
\hline \multicolumn{12}{|c|}{$91 \mathrm{mg} / \mathrm{dl}$} \\
\hline meter & mean & SD & $\mathrm{CV}$ & meter & mean & SD & $\mathrm{CV}$ & meter & mean & SD & $\mathrm{CV}$ \\
\hline 1 & 101 & 2.1 & 2.1 & 1 & 90 & 1.7 & 1.9 & 1 & 92 & 3.6 & 3.9 \\
\hline 2 & 97 & 3.7 & 3.8 & 2 & 97 & 2.6 & 2.7 & 2 & 91 & 2.1 & 2.3 \\
\hline 3 & 96 & 3.6 & 3.8 & 3 & 95 & 2.6 & 2.7 & 3 & 90 & 2.1 & 2.3 \\
\hline 4 & 95 & 3.3 & 3.5 & 4 & 100 & 2.0 & 2.0 & 4 & 92 & 1.6 & 1.7 \\
\hline 5 & 97 & 4.8 & 4.9 & 5 & 95 & 3.0 & 3.2 & 5 & 91 & 3.3 & 3.6 \\
\hline 6 & 98 & 1.6 & 1.6 & 6 & 96 & 2.2 & 2.3 & 6 & 95 & 2.5 & 2.6 \\
\hline 7 & 98 & 4.7 & 4.8 & 7 & 96 & 2.3 & 2.4 & 7 & 95 & 2.0 & 2.1 \\
\hline 8 & 91 & 4.3 & 4.7 & 8 & 97 & 3.8 & 3.9 & 8 & 88 & 4.3 & 4.9 \\
\hline 9 & 96 & 4.2 & 4.4 & 9 & 94 & 3.9 & 4.1 & 9 & 91 & 1.9 & 2.1 \\
\hline 10 & 96 & 2.3 & 2.4 & 10 & 93 & 3.1 & 3.3 & 10 & 91 & 1.1 & 1.2 \\
\hline mean & 96 & 3.5 & 3.6 & mean & 95 & 2.7 & 2.8 & mean & 92 & 2.4 & 2.6 \\
\hline \multicolumn{12}{|c|}{$123 \mathrm{mg} / \mathrm{dl}$} \\
\hline meter & mean & SD & $\mathrm{CV}$ & meter & mean & SD & $\mathrm{CV}$ & meter & mean & SD & $\mathrm{CV}$ \\
\hline 1 & 122 & 2.5 & 2.0 & 1 & 124 & 4.7 & 3.8 & 1 & 120 & 2.3 & 1.9 \\
\hline 2 & 127 & 3.0 & 2.4 & 2 & 127 & 3.0 & 2.4 & 2 & 124 & 3.7 & 3.0 \\
\hline 3 & 127 & 2.5 & 2.0 & 3 & 126 & 2.3 & 1.8 & 3 & 122 & 1.8 & 1.5 \\
\hline 4 & 124 & 5.7 & 4.6 & 4 & 129 & 2.8 & 2.2 & 4 & 129 & 2.3 & 1.8 \\
\hline 5 & 129 & 5.5 & 4.3 & 5 & 126 & 4.7 & 3.7 & 5 & 122 & 3.0 & 2.5 \\
\hline 6 & 125 & 2.3 & 1.8 & 6 & 129 & 4.0 & 3.1 & 6 & 123 & 3.9 & 3.2 \\
\hline 7 & 128 & 2.8 & 2.2 & 7 & 126 & 2.2 & 1.7 & 7 & 126 & 4.1 & 3.3 \\
\hline 8 & 125 & 4.8 & 3.8 & 8 & 128 & 8.2 & 6.4 & 8 & 119 & 3.8 & 3.2 \\
\hline 9 & 128 & 6.5 & 5.1 & 9 & 121 & 1.9 & 1.6 & 9 & 121 & 1.7 & 1.4 \\
\hline 10 & 124 & 6.6 & 5.3 & 10 & 120 & 4.0 & 3.3 & 10 & 119 & 1.6 & 1.3 \\
\hline mean & 126 & 4.2 & 3.3 & mean & 125 & 3.8 & 3.0 & mean & 122 & 2.8 & 2.3 \\
\hline \multicolumn{12}{|c|}{$169 \mathrm{mg} / \mathrm{dl}$} \\
\hline meter & mean & SD & $\mathrm{CV}$ & meter & mean & $\mathrm{SD}$ & $\mathrm{CV}$ & meter & mean & SD & $\mathrm{CV}$ \\
\hline 1 & 174 & 3.2 & 1.8 & 1 & 166 & 4.6 & 2.8 & 1 & 162 & 2.3 & 1.4 \\
\hline 2 & 172 & 5.6 & 3.3 & 2 & 169 & 3.3 & 2.0 & 2 & 168 & 3.3 & 2.0 \\
\hline 3 & 174 & 3.8 & 2.2 & 3 & 165 & 3.2 & 1.9 & 3 & 168 & 4.2 & 2.5 \\
\hline 4 & 173 & 5.9 & 3.4 & 4 & 167 & 5.2 & 3.1 & 4 & 169 & 5.8 & 3.4 \\
\hline
\end{tabular}




\begin{tabular}{|c|c|c|c|c|c|c|c|c|c|c|c|}
\hline 5 & 172 & 5.8 & 3.4 & 5 & 171 & 3.0 & 1.8 & 5 & 168 & 3.2 & 1.9 \\
\hline 6 & 173 & 4.9 & 2.8 & 6 & 165 & 5.1 & 3.1 & 6 & 166 & 1.9 & 1.1 \\
\hline 7 & 173 & 2.9 & 1.7 & 7 & 172 & 3.2 & 1.9 & 7 & 170 & 2.8 & 1.6 \\
\hline 8 & 172 & 3.5 & 2.0 & 8 & 171 & 2.8 & 1.6 & 8 & 163 & 5.3 & 3.3 \\
\hline 9 & 174 & 3.6 & 2.1 & 9 & 168 & 2.9 & 1.7 & 9 & 165 & 4.8 & 2.9 \\
\hline 10 & 170 & 4.6 & 2.7 & 10 & 176 & 3.8 & 2.2 & 10 & 164 & 2.9 & 1.8 \\
\hline mean & 173 & 4.4 & 2.6 & mean & 169 & 3.7 & 2.2 & mean & 166 & 3.6 & 2.2 \\
\hline \multicolumn{12}{|c|}{$281 \mathrm{mg} / \mathrm{dl}$} \\
\hline meter & mean & SD & $\mathrm{CV}$ & meter & mean & SD & $\mathrm{CV}$ & meter & mean & SD & $\mathrm{CV}$ \\
\hline 1 & 284 & 5.8 & 2.0 & 1 & 283 & 5.6 & 2.0 & 1 & 281 & 6.8 & 2.4 \\
\hline 2 & 283 & 8.7 & 3.1 & 2 & 284 & 5.3 & 1.9 & 2 & 283 & 5.0 & 1.8 \\
\hline 3 & 285 & 12.0 & 4.2 & 3 & 285 & 6.9 & 2.4 & 3 & 290 & 11.4 & 3.9 \\
\hline 4 & 291 & 8.7 & 3.0 & 4 & 292 & 3.8 & 1.3 & 4 & 286 & 8.0 & 2.8 \\
\hline 5 & 295 & 6.8 & 2.3 & 5 & 289 & 7.1 & 2.5 & 5 & 292 & 3.6 & 1.2 \\
\hline 6 & 302 & 6.1 & 2.0 & 6 & 297 & 5.6 & 1.9 & 6 & 284 & 4.9 & 1.7 \\
\hline 7 & 298 & 6.7 & 2.2 & 7 & 296 & 5.2 & 1.8 & 7 & 293 & 7.0 & 2.4 \\
\hline 8 & 291 & 4.6 & 1.6 & 8 & 299 & 4.7 & 1.6 & 8 & 283 & 4.1 & 1.4 \\
\hline 9 & 297 & 9.3 & 3.1 & 9 & 289 & 2.0 & 0.7 & 9 & 286 & 9.0 & 3.1 \\
\hline 10 & 293 & 9.9 & 3.4 & 10 & 291 & 5.5 & 1.9 & 10 & 288 & 5.5 & 1.9 \\
\hline mean & 292 & 7.9 & 2.7 & mean & 291 & 5.2 & 1.8 & mean & 287 & 6.5 & 2.3 \\
\hline
\end{tabular}

Table 6. Summary of lot 1,2 and 3

\begin{tabular}{|c|c|c|c|c|c|c|c|}
\hline \multirow{2}{*}{\multicolumn{2}{|c|}{$\begin{array}{c}\text { Summary of lot } \mathbf{1 , 2} \text { and } 3 \\
\text { Blood Conc. Level }\end{array}$}} & \multirow{2}{*}{$\begin{array}{c}\text { System } \\
\mathrm{N}\end{array}$} & \multicolumn{5}{|c|}{ Beurer GL44 } \\
\hline & & & $41 \mathrm{mg} / \mathrm{dl}$ & $91 \mathrm{mg} / \mathrm{dl}$ & $123 \mathrm{mg} / \mathrm{dl}$ & $169 \mathrm{mg} / \mathrm{dl}$ & $281 \mathrm{mg} / \mathrm{dl}$ \\
\hline \multirow{3}{*}{ Mean } & Lot \#1 & 100 & 36 & 96 & 126 & 172 & 292 \\
\hline & Lot \#2 & 100 & 34 & 95 & 125 & 169 & 290 \\
\hline & Lot \#3 & 100 & 31 & 92 & 122 & 166 & 287 \\
\hline \multicolumn{2}{|c|}{ Pooled mean } & 300 & 34 & 94 & 125 & 169 & 290 \\
\hline \multirow{3}{*}{ SD } & Lot \#1 & 100 & 1.4 & 3.5 & 4.2 & 4.4 & 7,9 \\
\hline & Lot \#2 & 100 & 1.5 & 2.7 & 3.8 & 3.7 & 5,2 \\
\hline & Lot \#3 & 100 & 1.6 & 2.4 & 2.8 & 3.6 & 6,5 \\
\hline \multicolumn{2}{|c|}{ Pooled SD } & 300 & 1,5 & 2.9 & 3.6 & 3.9 & 6.5 \\
\hline \multirow{3}{*}{ CV $(\%)$} & Lot \#1 & 100 & 3.8 & 3.6 & 3.3 & 2.5 & 2,7 \\
\hline & Lot \#2 & 100 & 4.5 & 2.8 & 3.0 & 2.2 & 1,8 \\
\hline & Lot \#3 & 100 & 5.1 & 2.7 & 2.3 & 2.2 & 2,3 \\
\hline \multicolumn{2}{|c|}{ Pooled CV (\%) } & 300 & 4,5 & 3.0 & 2.9 & 2.3 & 2.3 \\
\hline \multicolumn{2}{|c|}{ Blood Conc. Level } & $\mathrm{N}$ & $41 \mathrm{mg} / \mathrm{dl}$ & $91 \mathrm{mg} / \mathrm{dl}$ & $123 \mathrm{mg} / \mathrm{dl}$ & $169 \mathrm{mg} / \mathrm{dl}$ & $281 \mathrm{mg} / \mathrm{dl}$ \\
\hline \multicolumn{2}{|c|}{ pooled mean } & 300 & 34 & 94 & 125 & 169 & 290 \\
\hline \multicolumn{2}{|c|}{ pooled SD } & 300 & 1.5 & 2.9 & 3.6 & 3.9 & 6.5 \\
\hline \multicolumn{2}{|c|}{ pooled CV (\%) } & 300 & 4.5 & 3.0 & 2.9 & 2.3 & 2.3 \\
\hline
\end{tabular}

The validation of the glucose meter system Beurer GL44 was revealed in all concentration ranges according norm EN ISO 15197:2015, the intra-assay precision was expressed as pooled CV $\leq$ $5 \%$ and pooled standard deviation within the $95 \%$ confidence interval. The pooled coefficient of variation and the pooled standard deviation with a confidence interval of $95 \%$ represent appropriate and conclusive criteria for assessing the quality of the test system. The generated data demonstrate accurate and reliable results for the tested device.

\section{Acknowledgment}

Beurer $\mathrm{GmbH}$ were permitted to review and comment on the manuscript, but final decision on content was retained by the authors.

\section{Conflicts of interest}

The author(s) declared the following potential conflicts of interest with respect to the research, authorship, and/or publication of this article: All authors are employees of the Institute of Diabetes, Karlsburg, Germany, which carries out studies evaluating blood glucose meter systems on behalf of various companies.

\section{Funding}

The author(s) disclosed receipt of the following financial support for the research, authorship, and/or publication of this article: This study was funded by Beurer GmbH Soflinger Str 218, 89077 Ulm Germany.

\section{References}

1. Klonoff DC, Prahalad P (2015) Performance of cleared blood glucose monitors. $J$ Diabetes Sci Technol 9: 895-910. [Crossref]

2. International Organization for Standardization. In vitro diagnostic test systemsrequirements for blood-glucose monitoring systems for self-testing in managing diabetes mellitus. ISO 15197:2013.

3. Baumstark A, Schmid C, Pleus S, Rittmeyer D, Haug C, et al. (2014) Accuracy assessment of an advanced blood glucose monitoring system for self-testing with three reagent system lots following ISO 15197:2013. J Diabetes Sci Technol 28: 1241-1242. [Crossref]

4. International Organization for Standardization. In vitro diagnostic test systemsrequirements for blood-glucose monitoring systems for self-testing in managing diabetes mellitus. EN ISO 15197: 2003. 
5. Parkes JL, Slatin SL, Pardo S, Ginsberg BH (2000) A new consensus error grid to evaluate the clinical significance of inaccuracies in the measurement of blood glucose. Diabetes Care 23: 1143-1148. [Crossref]
6. Bland JM, Altman DG (1986) Statistical methods for assessing agreement between two methods of clinical measurement. Lancet 307-310. [Crossref]

Copyright: (O2019 Salzsieder E. This is an open-access article distributed under the terms of the Creative Commons Attribution License, which permits unrestricted use, distribution, and reproduction in any medium, provided the original author and source are credited. 